www.jmscr.igmpublication.org

Impact Factor 5.244

Index Copernicus Value: 83.27

ISSN (e)-2347-176x ISSN (p) 2455-0450

crossref DOI: _https://dx.doi.org/10.18535/jmscr/v4i10.102

Journal Of Medical Science And Clinical Research

IGM Publication

An official Publication of IGM Publication

\title{
Psychiatric Co-Morbidity in Patients with Attempted Suicide- A Hospital Based Study
}

\author{
Authors \\ Junaid Nabi ${ }^{1}$, Rakesh Ghildiyal ${ }^{2}$, Mohammed Sarwar Mir ${ }^{3}$, Nowsheen Zaffer ${ }^{4}$, \\ Darpan Kaur ${ }^{5}$, Ajaz Ahmad Suhaff ${ }^{6}$ \\ ${ }^{1}$ Registrar, Department of Psychiatry, SKIMS MC, Srinagar \\ ${ }^{2}$ Professor \& HOD, Department of Psychiatry, MGM medical College, Navi Mumbai \\ ${ }^{3}$ Post Graduate, Department of Hospital Administration, SKIMS, Srinagar \\ ${ }^{4}$ Senior Resident, Department of Hospital Administration, SKIMS, Srinagar \\ ${ }^{5}$ Associate Professor, Department of Psychiatry, MGM medical College, Navi Mumbai \\ ${ }^{6}$ Post Graduate, Department of Psychiatry, SKIMS MC, Srinagar \\ Corresponding Author \\ Mohammed Sarwar Mir \\ Email: mohammedsarwarmir@gmail.com
}

\begin{abstract}
Suicide is fatal act that represents the person's wish to die. There is a range, however, between thinking about suicide and acting it out. Some persons have ideas of suicide that they will never act on. In all countries, suicide is now one of the three leading causes of death among people. Until recently, the suicide rate was highest for the elderly, but now suicide predominates in younger people. In psychological sciences, the term stress is used to denote an influence that is disquieting or disruptive to a person's emotional status that cannot be mastered or encompassed within a reasonable period of time. Since there is paucity of relevant data from Maharashtra, this study was designed to find the personality traits in patients of suicidal attempt in a tertiary care teaching hospital in Navi Mumbai. Hundred successive patients presents with history of attempted suicide who filled inclusion and exclusion criteria were taken up for the study and administered the International Personality Disorder Examination (IPDE) scale for evaluation of personality traits. Each patient was informed about the purpose of interview; his/her consent was obtained and strict confidentiality was ensured. General description, demographic data and psychiatric history were recorded using the self designed proforma and the IPDE. Majority of the suicide attempters (58\%) were of young age group (18-25) years with female predominance (62\%) were unmarried (59\%) and belonged to Hindu (87\%). Major Depressive Disorder was main psychiatric co-morbidity seen with $28 \%$ followed by alcohol dependence (21\%) and panic disorder with 13\%. Major Depressive Disorder was predominant co-morbidity found in patients of attempted suicide.

Keywords: Suicide, Major Depressive Disorder, attempted suicide.
\end{abstract}

\section{INTRODUCTION}

Suicide is derived from Latin word for "self murder". It is fatal act that represents the person's wish to die. There is a range, however, between thinking about suicide and acting it out. Some persons have ideas of suicide that they will never act on; some plan for days, weeks, or even years before acting; and others take their lives 
seemingly on impulse, without premeditation. ${ }^{1}$ Freud thought that the study of melancholia, i.e. of depressive illness with strong suicidal tendencies might provide the answer. He interpreted the urge to self destruction as an attack against a loved person with whom the individual had identified himself. This theory implied that what appeared to be destruction was at least partly an act of homicide i.e. directed against another person. Up to this time aggression was regarded as a perversion of the sexual drive and as a reaction to frustration. Many aspects of the human behaviour could be understood as the result of the interplay between sexual drive and death instinct or in psychological terms as the expressions of the interplay of love and hate. ${ }^{2}$ Shneidman classified non-fatal suicidal acts according to person's statements about his intentions to bring on his death as intentional, sub intentional, unintentional and contra intentional, the contra intentional group being excluded as they did not take any risk but none of these terms could replace the more widely accepted term "attempted suicide". ${ }^{3}$ In all countries, suicide is now one of the three leading causes of death among people. Until recently, the suicide rate was highest for the elderly, but now suicide predominates in younger people, both in absolute and relative terms, in a third of all countries. During the past decade, there have also been dramatic and disturbing increases in report of suicide among youth. ${ }^{4}$ Suicide risk and protective factors and their interaction form the empirical base for suicide prevention. Risk factors are associated with the greater potential for suicide and suicide behavior. Mental disorders, previous suicide attempts, hopelessness and psychological pain associated with easy access to lethal methods constitute important elements in the precipitation of the suicide. ${ }^{5}$

Suicide is among the leading causes of death worldwide. ${ }^{6,7}$ Although the etiology of suicide is not well-understood, numerous studies have shown that the presence of mental disorders is one of the strongest risk factors for suicide attempts and suicide deaths. ${ }^{8,9}$ Indeed, psychological autopsy studies suggest that more than $90 \%$ of people who die by suicide have a diagnosable mental disorder, ${ }^{10}$ with similar figures reported among clinical samples of suicide attempters. ${ }^{11}$

In psychological sciences, the term stress is used to denote an influence that is disquieting or disruptive to a person's emotional status that cannot be mastered or encompassed within a reasonable period of time. In simpler form, a stress is an adaptive challenge or task. A distinction must be made between stresses that are necessary and essential part of living and stresses that may overwhelm the coping mechanisms available to a person and contribute to a maladaptive outcome like mental illness. Psychological stresses include those of separation, pain, death, illness, disapproval, losses, change in residence or work etc. ${ }^{12}$ Suicide is strongly associated with stress causing mental illness. ${ }^{13}$ Although it is clear that mental disorders in general are associated with suicidal behavior, research has not yet revealed which disorders uniquely predict these outcomes. This is because most studies have examined the associations between individual disorders and suicidal behavior. ${ }^{14,15,16}$ Therefore, this study was designed to find the personality traits in patients of suicidal attempt in a tertiary care teaching hospital in Navi Mumbai.

\section{MATERIAL AND METHODS}

This was a prospective, observational, descriptive study conducted in the department of Psychiatry at a tertiary care teaching hospital in Navi-Mumbai. Ethical clearance was obtained from the Institutional Ethics Committee. The sample size included 100 patients surveyed during the study period. The study included adult patients between the age group 18 to 60 years with history of attempted suicide and referred to Psychiatry Department for evaluation. Patients not willing for participation, didn't give informed consent, critically ill and accidental self-harm were excluded. Successive patients satisfying the inclusion and exclusion criteria were taken up for 
the study and administered the Mini International Neuropsychiatric Interview (MINI) for evaluation of personality morbidity. Each patient was informed about the purpose of interview; his/her consent was obtained and strict confidentiality was ensured. The interview was conducted as soon as possible after the patient had satisfactorily recovered medically and was able to co-operate for the interview. Those patients referred to Psychiatry OPD for evaluation were interviewed in the outpatient department itself and other patients were interviewed in their respective wards of initial admission. General description, demographic data and psychiatric history were recorded using the self-designed study proforma and the MINI.

\section{Research instrument}

1) Study case record /proforma: It consisted of a self-designed interview schedule to record the socio-demographic data, the psychiatric history Mini International Neuropsychiatric Interview (MINI) and mental status examination.

2) Mini International Neuropsychiatric Interview (MINI): The MINI is a short structured diagnostic interview developed jointly by psychiatrists and clinicians for ICD-10 and DSM-IV psychiatric disorders. It has an administration time of approximately 15 minutes and is used as a short, accurate structured psychiatric interview for clinical trials and epidemiological studies. It has high kappa value ( 0.5 and greater), sensitivity ( 0.7 and greater), specificity/negative predictive value (0.85 and higher) and positive predictive values ( 0.75 and greater for neurotic disorders). ${ }^{28}$

Statistics: Data obtained was then entered in Microsoft excel and analyzed in Statistical Package for the Social Sciences (SPSS. version 17) for descriptive statistics.

\section{Objectives}

1. To find out the socio-demographic details of patients presenting with attempted suicide.
2. To study the prevalence and types of psychiatric disorders with Mini International Neuropsychiatric Interview (MINI) scale in patients presenting with attempted.

\section{RESULTS}

In this study, one hundred $(n=100)$ participants with attempted suicide were analyzed.

Table 1: Summarizes the characteristic and sociodemographic details of the participants.

\begin{tabular}{|c|c|c|}
\hline \multicolumn{2}{|l|}{ Characteristics } & $\begin{array}{l}\text { Value } \\
\text { (Percentage) }\end{array}$ \\
\hline \multicolumn{2}{|c|}{ Participants with Attempted suicide } & 100 \\
\hline \multirow[t]{4}{*}{ Age (years) } & $18-25$ & $58(58 \%)$ \\
\hline & $26-35$ & $25(25 \%)$ \\
\hline & $36-45$ & $11(11 \%)$ \\
\hline & $46-60$ & $6(6 \%)$ \\
\hline \multirow[t]{2}{*}{ Gender } & Male & $38(38 \%)$ \\
\hline & Female & $62(62 \%)$ \\
\hline \multirow[t]{3}{*}{ Marital status } & Married & $59(59 \%)$ \\
\hline & Unmarried & $41(41 \%)$ \\
\hline & Divorce & $0(0 \%)$ \\
\hline \multirow[t]{2}{*}{ Family type } & Nuclear & $55(55 \%)$ \\
\hline & Joint & $45(45 \%)$ \\
\hline \multirow[t]{5}{*}{ Education } & Illiterate & $11(11 \%)$ \\
\hline & Primary & $39(39 \%)$ \\
\hline & Secondary & $25(25 \%)$ \\
\hline & Graduation & $15(15 \%)$ \\
\hline & Post-graduation & $10(10 \%)$ \\
\hline \multirow[t]{4}{*}{ Occupation } & Student & $38(38 \%)$ \\
\hline & Salaried & $33(33 \%)$ \\
\hline & Business & $22(22 \%)$ \\
\hline & Unemployment & $7(7 \%)$ \\
\hline \multirow[t]{2}{*}{ Mode of suicide } & $\begin{array}{l}\text { Organophosphorus } \\
\text { compounds }\end{array}$ & $88(88 \%)$ \\
\hline & $\begin{array}{l}\text { Benzodiazepine } \\
\text { overdose }\end{array}$ & $12(12 \%)$ \\
\hline \multirow{2}{*}{$\begin{array}{l}\text { History of stressors } \\
\text { prior to the suicidal } \\
\text { attempt }\end{array}$} & Yes & $54(54 \%)$ \\
\hline & No & $46(46 \%)$ \\
\hline \multirow{2}{*}{$\begin{array}{l}\text { History of previous } \\
\text { suicidal attempt in the } \\
\text { past }\end{array}$} & Yes & $18(18 \%)$ \\
\hline & No & $88(88 \%)$ \\
\hline
\end{tabular}


Table 2 shows Males were 38\% $(\mathrm{n}=38)$ and females were $62 \%(n=62)$. Majority $(58 \%)$ were young adults in the age group of 18 to 25 years. Married were 59\% ( $\mathrm{n}=59)$. In this study, organophosphorus compound poisoning (83\%) followed by benzodiazepine overdose were the commonest mode of attempted suicide and $18 \%$ had history of previous suicide attempt in the past.

Table 2: Stressors prior to suicidal attempt and status of social support in the participants

\begin{tabular}{|l|l|l|}
\hline \multicolumn{2}{|l|}{ Characteristics } & Value (percentage) \\
\hline $\begin{array}{l}\text { Stressors } \\
\text { prior to } \\
\text { suicidal } \\
\text { attempt }\end{array}$ & Economic/ finance & $11(11 \%)$ \\
\cline { 2 - 3 } & Support & $10(10 \%)$ \\
\cline { 2 - 3 } & Housing & $8(8 \%)$ \\
\cline { 2 - 3 } & Occupation & $7(7 \%)$ \\
\cline { 2 - 3 } & Environment & $5(5 \%)$ \\
\cline { 2 - 3 } & Education & $3(3 \%)$ \\
\hline Social support & Poor & $78(78 \%)$ \\
\cline { 2 - 3 } & Good & $22(22 \%)$ \\
\hline
\end{tabular}

Table 2 -In this study, (44\%) participants had history of stressors prior to the suicidal attempt, among which problems of occupation and housing was common. In this study, $78 \%$ had poor social support as perceived by the participants.

Table 3: Psychiatric co-morbidities with suicidal attempt as per the MINI

\begin{tabular}{|l|l|}
\hline Psychiatric co-morbidity & Value (Percentage) \\
\hline MDD & $28(28 \%)$ \\
\hline Alcohol Dependence & $21(21 \%)$ \\
\hline Panic Disorder & $13(13 \%)$ \\
\hline Dysthymia & $12(12 \%)$ \\
\hline GAD & $10(10 \%)$ \\
\hline OCD & $9(9 \%)$ \\
\hline PTSD & $7(7 \%)$ \\
\hline
\end{tabular}

Table 3-Major Depressive Disorder was the predominant personality co-morbidity (28\%) observed in the suicide attempters in this study, followed by Alcohol Dependence (21\%) and Panic Disorder (13\%). There was also a significant association $(\mathrm{P}<0.05)$ between psychiatric co-morbidity and education as well as with social support.

\section{DISCUSSION}

World Health Organization has reported that suicide is a serious public health problem. ${ }^{17}$ In this study an attempt has been made to study the different types of psychiatric co-morbidities in patients of attempted suicide in a tertiary care hospital Navi Mumbai. In India, suicidal behaviour is condemned socially and punished legally under section 309 of Indian Penal Code. ${ }^{18}$ The state police is required to keep the record of all the cases of suicide. Every registered medical practitioner is to inform immediately to the attached police station about every case of alleged poisoning, burns, multiple injuries, hanging/ strangulation and every case of road accident. There were predominantly more males (38\%) than females $(62 \%)$ in our study. which is in agreement with the findings of (Anderson 2002) ${ }^{19}$, according to Anderson suicide attempts are more common among female than males. Out of hundred cases of attempted suicide, $58 \%$ of the patients were in the age group of 18-25 years. WHO (2001) reported that during the past decade, there have also been dramatic and disturbing increases in report of suicide among youth which is in accordance with our study. Similar to other Indian studies, majority (59\%) of patients of attempted suicide were married. ${ }^{20}$ This suggests that at least in the Indian context, marriage does not provide a buffer against suicide. Over half $(59 \%)$ of the sample patients were from nuclear families. This is similar to the findings reported by Narang et al (2000) and Srivastava MK et al (2004) where patients from nuclear families were found to be vulnerable for suicide. ${ }^{21,22}$

$39 \%$ of the patients were educated only up to the primary level. This is similar to findings in many other Indian studies, which suggests lower educational achievement as a risk factor for suicide attempt. ${ }^{21,23}$ Similar to a study by Srivastava MK et al (2004), there was a preponderance $(91 \%)$ of Hindus in the sample of attempted suicide patients. This suggests that religion could be a factor which acts as buffer against the suicidal act. On the other hand, it could 
also be due to the fact majority of Indians are Hindus and this could bias the sample population. This reasoning has also been supported by a prospective Western study that the sociodemographic factors in suicide attempters did not differ from general population. ${ }^{24}$ Contrary to study by Beghi (2010) unemployment was not found to be a risk factor for suicide attempt. ${ }^{25}$ Thirty-eight percent of the study sample patients were students, $33 \%$ were salaried, $22 \%$, ran their own business and only $7 \%$ were unemployed. Low representation of unemployment in the sample study in contrast to Western study may be due to difficulty in its identification in agrarian rather than in industrialized countries and also that lower need of employment in students and in most females of the sample patients who were housewives. $^{22}$

In our study, poisoning was the most common method adopted for attempting suicide. $83 \%$ of the subjects used this method and organophosphorus compounds were most common agent. B Runeson et $\mathrm{al}^{26}$ in 2010 found attempted suicide by poisoning was the most common method. Mohammed Sarwar Mir et al ${ }^{36}$ in 2016 found OP compounds were the most agents used for poisoning.

Studies show that only a small number of people who make suicide attempt, commit suicide later. ${ }^{27}$ Our study too had only $12 \%$ patients with history of previous suicide attempts. Also all of these had only one previous attempt. But more importantly, $17 \%$ patients committed suicide again within a period of 1 month, 33\% within 1 month to 1 year and $50 \%$ did so between a period of 1 to 2 years. This suggests that previous attempts of suicide are one of the strongest risk factors of repeat suicide attempt. Concurring with other Indian ${ }^{28}$ and Western studies ${ }^{24}$, there was high prevalence (44\%) of stressors prior to the suicidal attempt with $14 \%$ having problems with primary support group and $13 \%$ having economic problems. This may be due to poor problem solving skills that leads to cognitive constriction and an easy way out approach through annihilation. The "psychic pain" could be too much to bear for the attempters such that suicide is looked upon as "one and the only solution" to solve their problems. However the stressors may serve only as a precipitating factor and may not be a causal one. ${ }^{29}$ In this study, $68 \%$ had poor social support as perceived by the patient. This finding, similar to other studies, reflects that presence of adequate social support is also a factor of importance in suicide attempts.

The current study also concurs that mental disorders occupy a premier position in the matrix of causation of suicide, with major depressive disorder being the most important diagnosis related to suicide attempt. Alcohol use was the second most common disorder in our study. Robins et al. opined that suicide practically does not occur without the presence of mental illness, most commonly depression and alcoholism. ${ }^{30}$ There was significant association $\quad(\mathrm{P}<0.05)$ between psychiatric co-morbidity, low level of education and lack of social support. The reason could be as suggested by Suppapitiporn $\mathrm{S}$ et al (2004) where they concluded that patients who were depressed and attempted suicide were more likely to report having fewer friends and low level of social support as compared to other suicide attempters. $^{31} 88 \%$ patients in our study were having some psychiatric illness at the time of suicide attempt. This figure is much higher than the west reports. Psychiatric illness was found in $20 \%$ of suicide attempters by Lumsden Walker $(1980)^{32}$ There was predominance of Major depressive disorder, which was present in $28 \%$ in our sample. According to Sainsbury $(1953)^{33}$, approximately two thirds of suicides are linked with depressive illness. Weismann ${ }^{34}$ (1974) reported depression to be most common diagnostic entity in suicide attempters (35\%). MMA S Qusar et al in $2009^{35}$ found most common psychiatric diagnosis was Major Depressive Disorder in attempted suicide. $13 \%$ of our cases had dysthymia. $21 \%$ of patients had panic disorder. 


\section{CONCLUSION}

In this study we found that suicide attempt was more common in young adult males who were predominantly Hindu. More than half of the patients were married with most of them having only primary level education. More than 50\% patients belonged to nuclear families and there were a high number of students by occupation. Consumption of organo phosphorus compounds (OPC) was the predominant method used for attempting suicide. A large number of patients perceived poor social support and had stressors preceding the attempt. Housing problems and problems with occupation being most commonly elicited stressors. Patients with borderline personality traits were significantly associated to re-attempt suicide between the period of 1 to 2 years. Major depressive disorder and panic disorder were the predominant psychiatric comorbidity found in patients of attempted suicide.

Thus the above factors would have to be focused upon, in the management, and, during the counseling sessions of patients of attempted suicide.

\section{REFERENCES}

1. Sadock BJ, Sadock VA. Kaplan and Sadock's Synopsis of Psychiatry; 10th Ed, New York. Lippincott and Williams, 2007. Chapter 34, Emergency Psychiatric Medicine; p.897.

2. Freud S. Mourning and Melancholia. In: J. Strachey (Ed.\& Trans.), The Standard edition of the complete works of Sigmund Freud (Vol.14 , pp.159-171). Hogarth Press, London 1950

3. Shneidman ES. Orientations toward death: A vital aspect of the study of lives. International Journal of Psychiatry1966; 2:167-200

4. Houston K, Hawton K, Shepperd R. Suicide in young people aged 15-24: a psychological autopsy study. J Affect Disord. $2001 \quad$ Mar;63(1-3):159-70. PubMed PMID: 11246092.
5. Henriksson MM, Aro HM, Marttunen MJ, Heikkinen ME, Isometsä ET, Kuoppasalmi KI, Lönnqvist JK. Mental disorders and comorbidity in suicide. Am J Psychiatry.1993 Jun;150(6):935-40. PubMed PMID: 8494072.

6. Goldsmith SK, Pellmar TC, Kleinman AM, Bunney WE, editors.Reducing suicide: A national imperative. The National Academies Press; Washington, DC: 2002.

7. Nock MK, et al. Suicide and suicidal behaviors. Epidemiologic

Reviews. 2008;30 [PMC free article] [PubMed]

8. Harris EC, Barraclough B. Suicide as an outcome for mental disorders. A metaanalysis. British Journal of Psychiatry.1997;170:205-28. [PubMed]

9. Pokorny AD. Prediction of suicide in psychiatric patients. Report of a prospective study. Archives of General Psychiatry.1983;40:249-57. [PubMed]

10. Cavanagh JT, Carson AJ, Sharpe M, Lawrie SM. Psychological autopsy studies of suicide: a systematic review. Psychological

Medicine. 2003;33:395-405. [PubMed]

11. Beautrais AL, Joyce PR, Mulder RT, Fergusson DM, Deavoll BJ, Nightengale SK. Prevalence and comorbidity of mental disorders in persons making serious suicide attempts: a case-control study.American Journal of Psychiatry. 1996;153:1009-14. [PubMed]

12. Andrews G, Tennant C, Hewson DM, Vaillant GE. Life event stress, social support, coping style, and risk of psychological impairment. J Nerv Ment Dis.1978 May;166(5):307-16. PubMed PMID: 650194.

13. Moscicki EK. Epidemiology of completed and attempted suicide: Towards a frame work for prevention. Clinical neurosciences research 2001; 1:310-323 
14. Weissman MM, Klerman GL, Markowitz JS, Ouellette R. Suicidal ideation and suicide attempts in panic disorder and attacks.New England Journal of Medicine. 1989;321:1209-14. [PubMed]

15. Bostwick JM, Pankratz VS. Affective disorders and suicide risk: a reexamination. American Journal of Psychiatry. 2000;157:1925-32.[PubMed]

16. Phillips MR, Yang G, Li S, Li Y. Suicide and the unique prevalence pattern of schizophrenia in mainland China: a retrospective observational study. Lancet. 2004;364:1062-8.[PubMed]

17. World Health Organization. World Health Report-2002. HEALTH SYSTEM; improving performance. Ref type; Report

18. 18.Suicide Act (1961): 9 and 10 Eliz 2, ch. 60, HMSO

19. 19.Anderson-R.N.(2002) Deaths: Leading causes for 2000.National Vital Statics Report 50(16).Hyattsville,MD:National Centre For Health Statics

20. Srivastava MK, Sahoo RN, Ghotekar LH, Dutta S, Danabalan M, Dutta TK, Das AK. Risk factors associated with attempted suicide : a case control study. Indian J Psychiatry. 2004 Jan;46(1):33-8. PubMed PMID: 21206774; PubMed Central PMCID:PMC2912675.

21. Srivastava MK, Sahoo RN, Ghotekar LH, Dutta S, Danabalan M, Dutta TK, Das AK. Risk factors associated with attempted suicide : a case control study. Indian J Psychiatry. 2004 Jan;46(1):33-8. PubMed PMID: 21206774; PubMed Central PMCID:PMC2912675.

22. Narang RL, Mishra BP, Nitesh $M$. Attempted suicide in ludhiana. Indian $\mathbf{J}$ Psychiatry. 2000 Jan;42(1):83-7. PubMed PMID: 21407914; PubMed Central PMCID: PMC2957009.

23. Srivastava A. Psychological attributes and socio-demographic profile of hundred completed suicide victims in the state of
Goa, India. Indian J Psychiatry. 2013 Jul;55(3):268-72. doi: 10.4103/00195545.117147. PubMed PMID: 24082248; PubMed Central PMCID: PMC3777349..

24. Nordentoft M, Rubin P. Mental illness and social integration among suicide attempters in Copenhagen. Comparison with the general population and a fouryear follow-up study of 100 patients. Acta Psychiatr Scand. 1993 Oct;88(4):27885.PubMed PMID: 8256646.

25. Beghi M, Rosenbaum JF. Risk factors for fatal and nonfatal repetition of suicide attempt: a critical appraisal. Curr Opin Psychiatry. 2010 Jul;23(4):349-55. doi: 10.1097/YCO.0b013e32833ad783.

Review. PubMed PMID: 20520547.

26. Bo Runeson, Dag Tidemalm, Marie Dahlin, Paul Lichtenstein Niklas Långström,; Method of attempted suicide as predictor of subsequent successful suicide: national long term cohort study: BMJ 2010; 341:c3222 doi: 10.1136/bmj.C3222.

27. Stephine M. Leese. Suicidal behaviour in 20 adolescents. Br J Psychiatr 1969; 115: 479.

28. Badrinarayana A. Suicidal attempt in Gulbarga. Indian J Psychiatry. 1977;19:69-70.

29. Joseph Raj MA, Kumaraiah V, Bhide AV. Social and clinical factors related to deliberate self-harm. NIMHANS J. 2000;18:3-18.

30. Suppapitiporn S, Thavichachart N, Suppapitiporn S. Social support in depressed patients who attempted suicide. J Med Assoc Thai. 2004 Sep;87 Suppl 2:S266-71. PubMed PMID: 16083200.

31. Moscicki EK. Epidiomology of completed and attempted suicide: Towards a frame work for prevention. Clinical neurosciences research 2001, 1, 310-323 
32. Lumsden Walker W. Intentional self injury in school age children - A study of 50 cases. Jr of Adolescence 1980; 4: 355.

33. Sainsbury P. Suicide in London: An ecological study. 1955, Chapman, London.

34. Weissmann NM. The epidemiology of suicide attempts 1960 to 1971 . Arch Gen Psychiat 1974; 30: 737

35. MMA Shalahuddin Qusar, Nahid Mahjabin Morshed, MD Abul Kalam Azad, Md Abdul Kader, ET AL Psychiatric Morbidity Among Suicide Attempters Who Needed ICU Intervention: Bangabandhu Sheikh Mujib Medical University Journal, Vol 2, No 2 (2009)

36. Mohammed Sarwar Mir et al. Spectrum of Acute Poisoning in Kashmir. International Journal of Current Medical and Pharmaceutical Research. Vol. 2, Issue, 9, pp.712-714, September, 2016 